\title{
REPUBLIC OF BULGARIA - TRANSIT COUNTRY FOR REFUGEES
}

\author{
S. Panayotova*, D. Petrova \\ Faculty of Economics, Technical University - Gabrovo, Bulgaria
}

\begin{abstract}
The paper covers an important issue in national and international aspect: the migration processes and the legislation in Bulgaria. About 60,000 to 70,000 immigrants have been registered in the country but according to the National Statistical Institute (NSI) the number of immigrants residing in Bulgaria is between 300 and 350 thousand coming from more than 11 countries. The purpose of this study is to present an up-to-date picture of migration, in particular immigrants in Bulgaria, and their limited access to the labor market, health care, education, and social assistance. The authors use the methods of comparison, analysis, and data pooling. Secondary information from the authors' participation in the seminar Waves of Integration (TSUNAMI) in Caciulata, Romania, 2019 was also analyzed. The results of the survey show that the majority of the Bulgarian population perceives immigrants as a threat due to difficulties in their integration and in relation to the worse economic situation of the country compared to other European countries. In conclusion, migration in the country between 2017 and 2019, including illegal, is relatively low. The refugee crisis affects the Bulgarian population mainly politically and psychologically, and for asylum seekers Bulgaria is not a final destination but a transit territory.
\end{abstract}

Key words: migration, immigrants, integration, refugees, transit territory

\section{PURPOSE}

The purpose of this study is to present an upto-date picture of migration and in particular of immigrants in the country because refugees have limited access to the labor market, health care, education, and social assistance. The first Foreigners Act was adopted in the Republic of Bulgaria in 1998. (1) For the period 2005 2013, the National Program for the Integration of Refugees (NPIR) was adopted in the Republic of Bulgaria. The responsible institution for the implementation of the adopted NPIR is the State Agency for Refugees (SAR) under the Council of Ministers. The National Refugee Integration Program includes approximately 100 persons per year (60 adults and 40 children) who have received international protection. According to the UN definition, "an international migrant is a person who has lived for at least a year in a

\footnotetext{
*Correspondence to: Svetla Panayotova, Faculty of Economics, Technical University - Gabrovo, Address: 4 H. Dimitar, Gabrovo, 5300, Bulgaria, E-mail: svetla7561@abv.bg
}

country where he was not born." (2) According to D. Montiglio, the number of migrants from other countries living in Bulgaria is over 8,000 people. For 2017 it is as follows: Russia 30,950; Greece - 11,700; Turkey - 9,870; Ukraine - 9,640; Romania - 8,525. (3)

The Program receives annual financing from the state budget. Individuals can be granted refugee or humanitarian status under the Asylum and Refugees Act (ARA). Refugee status is granted to foreigners "who, due to reasonable fears of persecution based on race, religion, nationality, political opinion, or being members of a particular social group, are outside their country of origin and for these reasons cannot or do not wish to enjoy the protection of that state or to return to it". (4) Humanitarian status is granted to foreigners "who do not qualify for refugee status and who are unable or unwilling to receive protection from their country of origin, as they may be at real risk of serious harm, such as: 1) death penalty or execution, or 2) torture, inhuman or degrading treatment or punishment, or 3) serious threats to the life or person of a 
civilian due to wanton violence in the event of armed international or domestic conflict". (5)

Those wishing to join the NPIR are required to: Apply within a certain period of time following the receiving of protection for refugee status or humanitarian status; Pass an interview - a social worker from SAR will talk to them; Have an Individual Integration Plan drawn up for them; Applications and plans are reviewed by the Integration Committee - representatives of nongovernmental organizations (NGOs), UN High Commissioner for Refugees (UNHCR), Bulgarian Red Cross, other institutions related to the integration of asylum seekers in Bulgaria; Enter into an Integration Agreement - with specified rights and obligations of the parties. (6)

\section{METHODS}

We would like to emphasize the fact that for the current paper the used research methods refer to the study, analysis, comparison, and data pooling from previously conducted sociological surveys on the attitude of Bulgarian society towards migrants. Secondary information from a seminar including the participating countries /Greece, Italy, France, Portugal, Romania and Bulgaria/ on migration processes in these countries under the TSUNAMI project: Waves of Intergration, Caciulata, Romania - March - April 2019 was also analyzed.

The Republic of Bulgaria has adopted a Law for Entering, Residing and Leaving the Republic of Bulgaria of European Union Citizens and Members of Their Families. (7) It is lex specialis with regards the Law for the Foreigners in the Republic of Bulgaria. However, sometimes there is illegal immigration as the provisions of Article 279, Para. 5, of the Criminal Code which refers to illegal entering into the country or entering without following the legal procedures in place. In Bulgaria, however, there is the administrative absurdity that when a foreigner is defined as illegal, there is no way for them to become legal under Bulgarian law. (8) There are no mechanisms for legalizing illegal immigrants. They remain illegal forever. Such a foreigner must be expelled and enter the country again. However, when a foreigner is expelled they are banned from entering the country for a period of 10 years. This is an extremely restrictive sanction. There are thousands of people in Bulgaria who are not expelled, but are not legalized either.

The activities financed under the NBIR relate to: Placement; Social assistance; Bulgarian language training (level A1 and A2 of the Common European Framework of Reference for
PANAYOTOVA S., et al.

Languages); Health Insurance; Professional qualification and retraining (courses in hairdressing, cosmetics, fashion design, ICT literacy); Child care. $(9,10)$

According to statistics, the number of migrants headed for Bulgaria has doubled since 2007. About 60,000 to 70,000 immigrants have been registered. Despite that, according to the National Statistical Institute (NSI) the number of immigrants actually residing in the country is between 300 and 350 thousand. There are immigrants from Turkey, Russia, the Republic of Northern Macedonia, Moldova, Armenia, Seychelles, Jamaica, Nepal, Syria, Iraq and Pakistan. The Republic of Bulgaria is still a transit country and Western Europe is more attractive. There are persons who have integrated and own businesses, others are placed in refugee camps, and still others are from the EU. The integration of groups that do not have identification papers is most difficult. They do not have access to the labor market, health care, education, social assistance.

\section{RESULTS}

The results of the survey show that the majority of the Bulgarian population perceives immigrants as a threat due to difficulties in their integration and in relation to the worse economic situation of the country compared to other European countries. The results of the implementation of the research methods are presented in tabular form /tables 1, 2, 3/ and are illustrated with figures $-1,2,3$.

The number of persons seeking asylum in Bulgaria marked a significant increase in the period 2013 - 2015 (Figure 1).

According to SAR data, in the period 1993 2012 the number of asylum seekers in Bulgaria was about 1,100 people on average per year, with the highest number of 2,900 people reached in 2002. In 2013, 2014, and 2015 there was a significant increase in the flow of refugees to the country, with the total number of asylum applications reaching 7,100, 11,100, and 20,400 people (following the events in North Africa - the Arab Spring, also following the events in Asia, Iraq and Afghanistan). (11) The highest number of illegal immigrants comes from Iraq, Afghanistan, Palestine, and more recently from Syria. However, it cannot be stated that there is a huge flow of immigrants to Bulgaria, because it is not an economically attractive country for them. They are placed in the so-called refugee camps for temporary settlement until they are issued 
identification papers. Currently, Bulgaria is protected from mass illegal immigration $(1,000$ people per year) which, compared to countries from the Adriatic and Greece, is a very low number. (12)

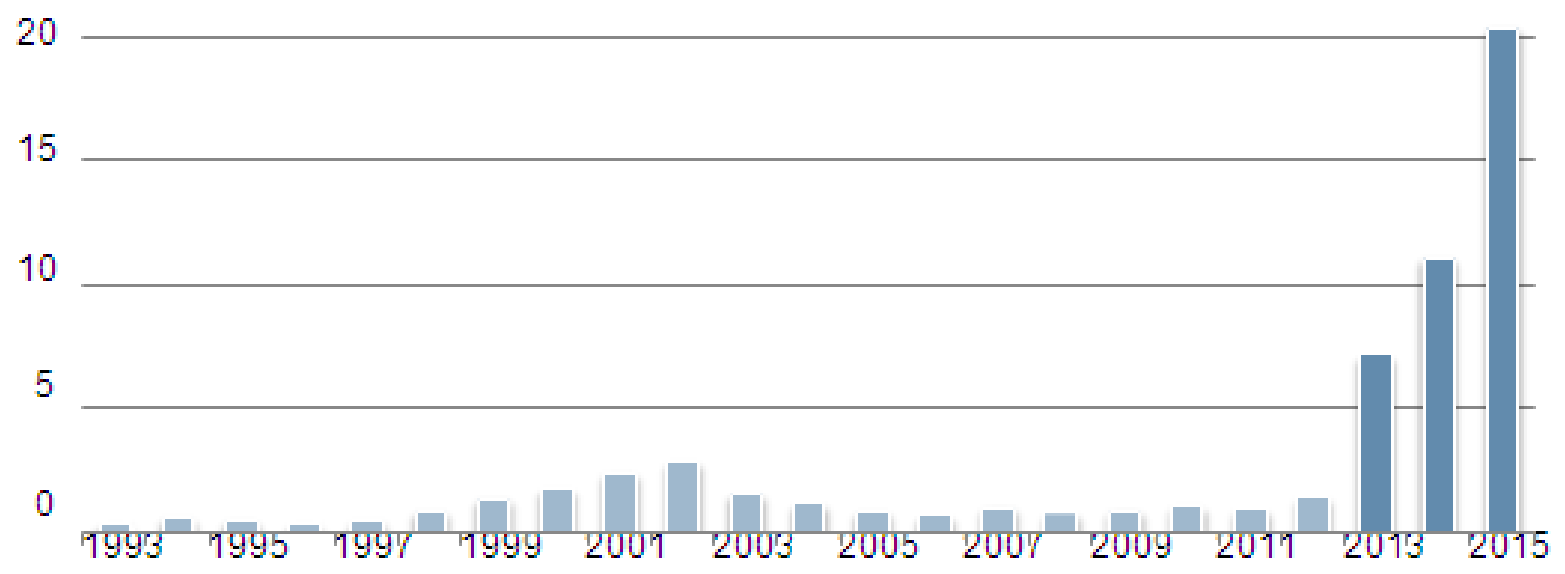

Figure 1. Number of asylum applicants in Bulgaria, in thousands of people (SAR source)

The age structure of asylum applicants is dominated by persons in active working age between 18 and 34 years, but there is an increase in the group of minors under 18 years (Figure 2).
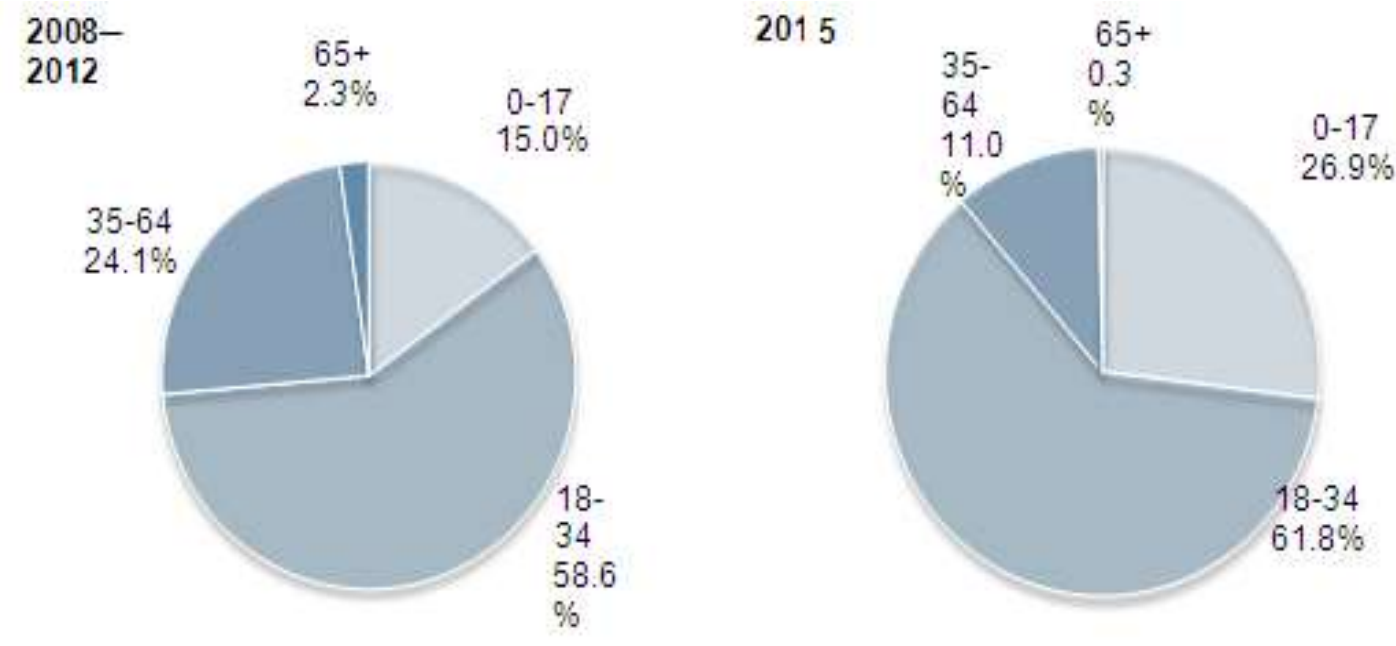

Figure 2. Age structure of persons seeking international protection in Bulgaria, \% (SAR source)

In 2015 the share of asylum seekers between the ages of 18 and 34 reached $61.8 \%$ of all applicants, which is an increase of $3.1 \%$ compared to the average share for this age group for the period $2008-2012$. For persons under 18 years of age there is even more significant increase, as their share in 2015 increased by $11.9 \%$ compared to 2008 - 2012. The share of persons between the ages of 35 and 64, as well as those over 65 years old is characterized by a decrease for the period under review. The trends in the age structure of asylum seekers in Bulgaria show an increasing number of the youngest, as well as the number of people entering active working age. In order to assess the prospects for their successful integration into the socioeconomic life of the host country, it is necessary to consider the educational structure of the asylum applicants.

The educational structure of persons seeking international protection shows a predominant and growing share of people with lower level educational degrees (Figure 3). 
2013

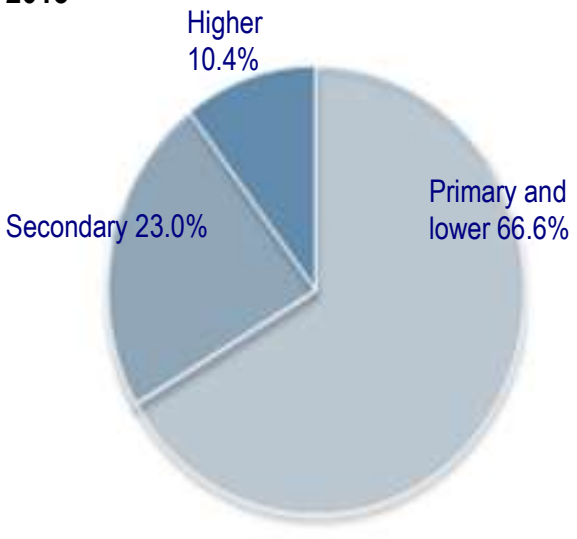

2015

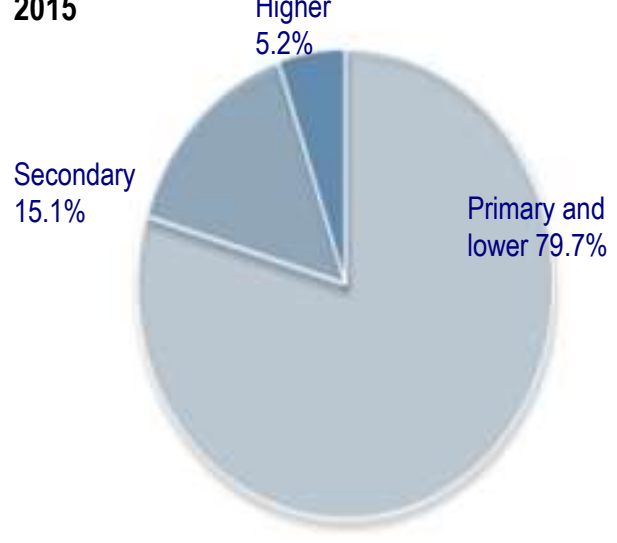

Figure 3. Educational structure of asylum applicants, \% (SAR source)

In the period 2013 - 2015 the group of persons with primary and lower level education increased by over $13 \%$ and reached $79.7 \%$ in 2015 . This unfavorable dynamics is mainly determined by the rapid increase of persons without an education degree, who from $11.8 \%$ in 2013 reached $24.6 \%$ in 2015 . The share of persons with primary education also increased to $30.5 \%$ in 2015 , and the share of those with secondary education decreased slightly compared to 2013, but remains comparable to the share of persons without an education degree. The share of secondary and higher education degree holders decreased significantly from $23 \%$ in 2013 to $15.1 \%$ in 2015 for persons with secondary education, and from $10.4 \%$ to $5.2 \%$ for persons with higher education. The unfavorable educational structure of the asylum applicants requires additional efforts/ expenses for increasing their employability and their inclusion in the active labor and social life of the country.

Table 1 shows data on persons who sought protection and received refugee or humanitarian status (Table 1).

Table 1. Main indicators for persons seeking protection who have received refugee or humanitarian status (SAR source, MoF)

\begin{tabular}{|l|c|c|c|c|c|}
\hline \multicolumn{1}{|c|}{ Years } & $\mathbf{2 0 1 3}$ & $\mathbf{2 0 1 4}$ & $\mathbf{2 0 1 5}$ & $\mathbf{2 0 1 6}$ & $\mathbf{2 0 1 7}$ \\
\hline $\begin{array}{l}\text { Number of persons seeking protection, } \\
\text { people }\end{array}$ & 7,144 & 11,081 & 20,391 & 26,726 & 29,893 \\
\hline $\begin{array}{l}\text { Number of persons granted status, } \\
\text { people }\end{array}$ & 2,462 & 7,000 & 5,597 & 7,404 & 8,307 \\
\hline $\begin{array}{l}\text { Number of persons granted status } \\
\text { and in working age (aged 18-64), } \\
\text { people }\end{array}$ & 1,540 & 4,335 & 3,475 & 4,606 & 5,168 \\
\hline
\end{tabular}

SAR information for the period $2013-2015$ was used in preparing the analysis, as 2013 is the year when the number of persons seeking international protection significantly increased. The numbers for 2016 and 2017 for the flow of refugees and the number of persons who have been granted status are obtained from the development of flows from 2013. Based on the data of SAR and Eurostat for the age structure of persons who have been granted status, the used data are for those who are of working age (between 18 and 64 years old) and could join the workforce. The average share in the total number of persons who have been granted status for the period 2013 - 2015 was used for analysis of the refugees of working age who received access to the labor market for the period $2016-2017$. 
Table 2. Difference between realistic (1) and baseline (2) data by years (Source MF)

\begin{tabular}{|c|c|c|c|c|}
\hline Years & 2014 & 2015 & 2016 & 2017 \\
\hline \multicolumn{5}{|l|}{ Labor force (aged $15-64)$} \\
\hline Difference between (2) and (1), \% & 0.00 & 0.00 & 0.01 & 0.01 \\
\hline Growth (1) on an annual basis, $\%$ & -0.42 & -0.85 & -0.26 & -0.08 \\
\hline Growth (2) on an annual basis, $\%$ & -0.42 & -0.84 & -0.26 & -0.08 \\
\hline \multicolumn{5}{|l|}{ Employed (15 - 64 years) } \\
\hline Difference between (2) and (1), \% & 0.00 & 0.00 & 0.00 & 0.00 \\
\hline Growth (1) on an annual basis, $\%$ & 1.32 & 0.91 & 0.57 & 0.64 \\
\hline Growth (2) on an annual basis, $\%$ & 1.32 & 0.91 & 0.57 & 0.64 \\
\hline \multicolumn{5}{|l|}{ Unemployed (aged 15-64) } \\
\hline Difference between (2) and (1), \% & 0.00 & 0.03 & 0.04 & 0.06 \\
\hline Growth (1) on an annual basis, $\%$ & -11.98 & -14.31 & -7.71 & -7.16 \\
\hline Growth (2) on an annual basis, $\%$ & -11.98 & -14.28 & -7.70 & -7.15 \\
\hline \multicolumn{5}{|l|}{ Unemployment rate (aged $15-64$ ) } \\
\hline Difference between (2) and (1), \% & 0.00 & 0.00 & 0.00 & 0.01 \\
\hline
\end{tabular}

It should be noted that the main goal of the Refugee Training and Employment Program is to ensure integration into the labor market of the unemployed persons with refugee or humanitarian status, through training in Bulgarian language, training for professional qualification, subsidized employment and employment in the primary labor market. Unemployed persons on a general basis are also enrolled in the program in order to increase the administrative capacity to work with refugees. There is no statistics as to what portion of the persons enrolled in the program are refugees and what portion are unemployed on a general basis, and due to the small number of people enrolled in it in general, as well as the fact that the number of refugees significantly exceeds the number of service staff in registration and reception centers, it is assumed in this paper that all participants in the program are refugees.

According to A. Gulubov, the difficulties in the participation of migrants in the labor market are caused primarily by ignorance of the Bulgarian language. (13)

\section{Data on the employment of immigrants aged 15 - 64. (Table 2)}

In 2014, 75 refugees were included in the program, and in 2015 their number amounted to 106 people. According to the National Action Plan for Employment the program provided employment to another 130 people in 2016. As the number of employed people has increased almost steadily each year since 2014, in 2017 it reached 158 people. In 2014, those who were again enrolled as unemployed amounted to $28 \%$ of the participants, and in 2015 they reached 53\%. Thus, $72 \%$ of the participants in 2014 were reported as employed in 2015 , as well as $47 \%$ of the unemployed in 2015 were reported as employed in 2016. For 2017, the number of employed refugees was obtained by comparing the average share of those who found a job in the past two years to the number of unemployed in the past year.

The results of the calculations show insignificant effect on the labor force (employed and unemployed) and the unemployment rate, due to the small number of refugees who register as unemployed (Table 3). 
PANAYOTOVA S., et al.

Table 3. Total number of employed and unemployed persons - change compared to the baseline, in number of people (Source MF)

\begin{tabular}{|c|c|c|c|c|}
\hline Year & \multicolumn{2}{|c|}{$\mathbf{2 0 1 6}$} & \multicolumn{2}{c|}{$\mathbf{2 0 1 7}$} \\
\hline Criteria & $\begin{array}{c}\text { Baseline } \\
\text { in thousand } \\
\text { people }\end{array}$ & $\begin{array}{c}\text { Realistic } \\
\text { compared to } \\
\text { baseline }\end{array}$ & $\begin{array}{c}\text { Baseline } \\
\text { in thousand } \\
\text { people }\end{array}$ & $\begin{array}{c}\text { Realistic } \\
\text { compared to } \\
\text { baseline }\end{array}$ \\
\hline Employed (aged 15-64) & 2970.7 & +50 & 2989.6 & +77 \\
\hline Unemployed (aged 15-64) & 301.6 & +130 & 280.0 & +158 \\
\hline
\end{tabular}

Table 3 shows data on employed and unemployed immigrants for the period 2016 2017. The calculations made based on the number of employed and unemployed persons in the realistic version compared to the baseline show the different degree of integration of refugees in the labor market. They are used as a basis for further assessments of the direct and indirect effects of policy implementation on other indicators. Based on the presented estimates of the impact of refugees on the number of employed and unemployed in the different options, the expected budgetary effects of their inclusion in the labor force are calculated. The author L. Kyuchukov shares that the Bulgarian society is burdened with a number of fears towards the refugees, but for a large part of the Bulgarian population these fears have not turned into hatred. (14) Good practices in the Republic of Bulgaria for the integration of refugees are: Pilot Integration Program 2016; Work with social mediators; Integration Program for Refugees of the Bulgarian Red Cross; Mentoring program of "Caritas - Sofia"; Center for Refugee and Migrant Integration "St. Anna" to "Caritas - Sofia". (15) According to the author A. Stoitsev, "Bulgaria has and maintains a strategy to support refugees. It includes a number of measures, which, however, are too difficult and cumbersome to implement." (16)

\section{CONCLUSIONS}

The following conclusions can be drawn from the analysis of employment, unemployment, and the integration of refugees in the Republic of Bulgaria:

- In the period following 2013 the number of persons seeking international protection in Bulgaria increased significantly compared to previous years. Although the number of persons granted refugee or humanitarian status is also increasing, there is a significant increase in cases of discontinued proceedings. This gives grounds to conclude that Bulgaria is not a final destination.

- A small proportion of those who received international protection and access to the labor market actively participate in the labor force, despite the fact that trends in the age structure of those granted refugee or humanitarian status show a dominant share of persons in active working age.

- The prospects for successful integration in the socio-economic life of the country of the potential additional labor force are worsened by many factors, such as the unfavorable educational level of the persons granted status, mainly lower educational levels, poor command of Bulgarian language and weak economic activity, especially of women, in the respective countries of origin.

- The unfavorable progress and expectations of increased migration flow in the coming years due to ongoing military and political conflicts in the countries of origin of asylum seekers require tighter controls on the implementation of refugee reception policies and additional efforts of integration.

- Refugees in Bulgaria need integration based on communication with people in the country where they have sought asylum.

\section{REFERENCES}

1. Spravochnik: Integratsiya na imigranti chesto sreshtani kazusi, Proekt „Nadgrazhdane na kapatsitet i suzdavane na aktivna platforma $\mathrm{v}$ podkrepa na politikata po integratsiya na imigranti” Dogovor za bezvuzmezdna finansova pomosht № $\mathrm{BG}$ EIF 2013/01-05.01, RSO „Maritsa”, p. 5, 2013

2. Montiglio, D., Migrantite v Bulgariya ot 1990 do 2017 g., p. 1, 


\section{PANAYOTOVA S., et al.}

https://www.foreigner.bg/migrantite-vbulgaria-ot-1990-do-2017-godina/, (10.05.2020)

3. Ibid. p. 1

4. Nikolova, A., N. Chernicherska, Bezhantsite $\mathrm{v}$ Bulgariya: pazar na truda $\mathrm{i}$ byudzhetni razhodi, Ministerstvo na finansite, p. 6, 2016.

5. Ibid. p. 6

6. Dobri praktiki za integratsiya na bezhantsi, Bulgarski suvet za bezhantsi i migranti, Po Proekt na Bulgarski suvet za bezhantsi i migranti, finansiran ot Vurhoven komisariat za bezhantsite na OON,p. 4

7. Spravochnik: Integratsiya na imigranti chesto sreshtani kazusi... p. 4

8. Spravochnik: Integratsiya na imigranti chesto sreshtani kazusi... p. 5

9. Nikolova, A., N. Chernicherska, Bezhantsite v Bulgariya... pp 9-10
10.Dobri praktiki za integratsiya na bezhantsi... pp 4-6

11.Spravochnik: Integratsiya na imigranti chesto sreshtani kazusi... p. 4

12.Ibid. p. 4

13.Gulubov, A., Migratsiya i integratsiya... p. 2

14.Kyuchukov, L., Vliyanie na bezhanskata kriza vurhu bulgarskoto obshtestvo i bulgarskata politika: strahove, no ne omraza, fondatsiya Friedrich Ebert, byuro Bulgariya, Sofia, p. 10, 2016.

15.Dobri praktiki za integratsiya na bezhantsi... pp 6-9

16.Stoitsev, A., $\quad$ Mezhdukulturna komunikatsiya - modeli za integratsiya na bezhantsite, Sofia, p. 1, 2014, http://ebox.nbu.bg/ssc15/view_lesson.php?i $\mathrm{d}=28,(30.03 .2019)$ 